Korneliy Tretyak*, Serhiy Periy*, Ihor Sidorov*, Lubov Babiy*

\title{
Complex High Accuracy Satellite and Field Measurements of Horizontal and Vertical Displacements of Control Geodetic Network on Dniester Hydroelectric Pumped Power Station (HPPS)
}

\section{Statement of the Problem}

Construction of large hydropower complex is accompanied by a significant technological impact on the environment. Large volumes of soil are redistributed, groundwater regime varies, there is the risk of deformation of the earth surface. One of the main methods of monitoring this dangerous phenomenon is the application of GNSS technology. The implementation of this method without a loss of coordinate accuracy depends on the conditions of horizon openness on the point of observations and the absence of objects causing multibeam effect, what is not always possible. This condition is not implemented on all points. Conducting high accuracy linear and angular observations in a complex with GNSS measurements will allow provide the necessary accuracy for the determination of the coordinates and their displacements.

\section{Main Research of the Problem}

Dniester Hydroelectric Pumped Power Station (HPPS) is located on the Dniester River in the Chernivtsi region of the Ukraine. The projected capacity of the station is $2.268 \mathrm{MW}$, and it is one of the largest HPPS in the world. The station is a part of the Dniester hydropower complex, consisting of: HPS-1 with a dam height $-45.0 \mathrm{~m}$, a length of the main reservoir $-220 \mathrm{~km}$ and the volume -3.0 billion $\mathrm{m}^{3}$ (operated since 1981); HPS-2 with length of buffer reservoir - $20 \mathrm{~km}$ and a volume $-78.0 \mathrm{~m}^{3}$ (operated since 1998); Dniester HPPS with volume of upper reservoir - 26.0 million $\mathrm{m}^{3}$ is under construction. In 2012 the first hydraulic unit of the station was put into operation.

\footnotetext{
* Lviv Politechnic National University, Lviv, Ukraine
} 
During the construction of the HPPS, large amounts of soil were moved: there were excavated 15.3 million $\mathrm{m}^{3}$, including an underground output of 426 thousands $\mathrm{m}^{3}$ and there were piled up 10.5 million $\mathrm{m}^{3}$. The mode of the hydropower complex functioning is characterized by seasonal and daily fluctuations in the water level in the reservoirs. The maximum value of the daily fluctuations, in accordance with the project, for the buffer reservoir may reach $9 \mathrm{~m}$ and for the upper reservoir $15 \mathrm{~m}$. These factors lead to changes in hydrodynamic loadings and changes of the stress-deformed state of the near-surface parts of the Earth crust [1, 2]. In this regard systematic geodetic monitoring on hydraulic constructions of HPPS and surrounding area becomes important. For such monitoring the control geodetic network of Dniester HPPS was established, which can be considered as a local geodynamic polygons. The geometric configuration of the control geodetic network points of the Dniester HPPS was created considering the geomorphological structure of the surrounding areas as well as the location of the manmade objects - buildings, structures, embankments, etc. Network points represent the tubular marks of long-term storage, enabling forced centering of geodetic instruments. Figure 1 shows the control geodetic network points on the left bank of the Dniester River.

The high-precision geodetic receivers of the satellite signals were used as the main equipment for measuring the horizontal displacements of the geodetic network points. Measurements on the points of the control geodetic network of HPPS have been implemented since 2004. Currently, 12 cycles of observations have been performed.

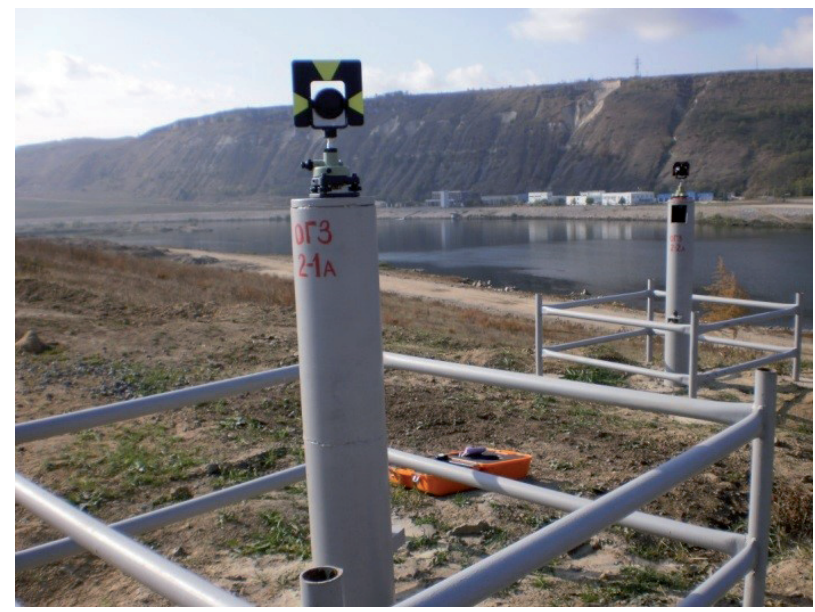

Fig. 1. Points of the control geodetic network on Dniester HPPS

In Figure 2 the general scheme for measuring vectors of control geodetic network of Dniester HPPS (October 2012) is presented; in Figure 3 the scheme of the control geodetic network points location on the satellite images is shown. 


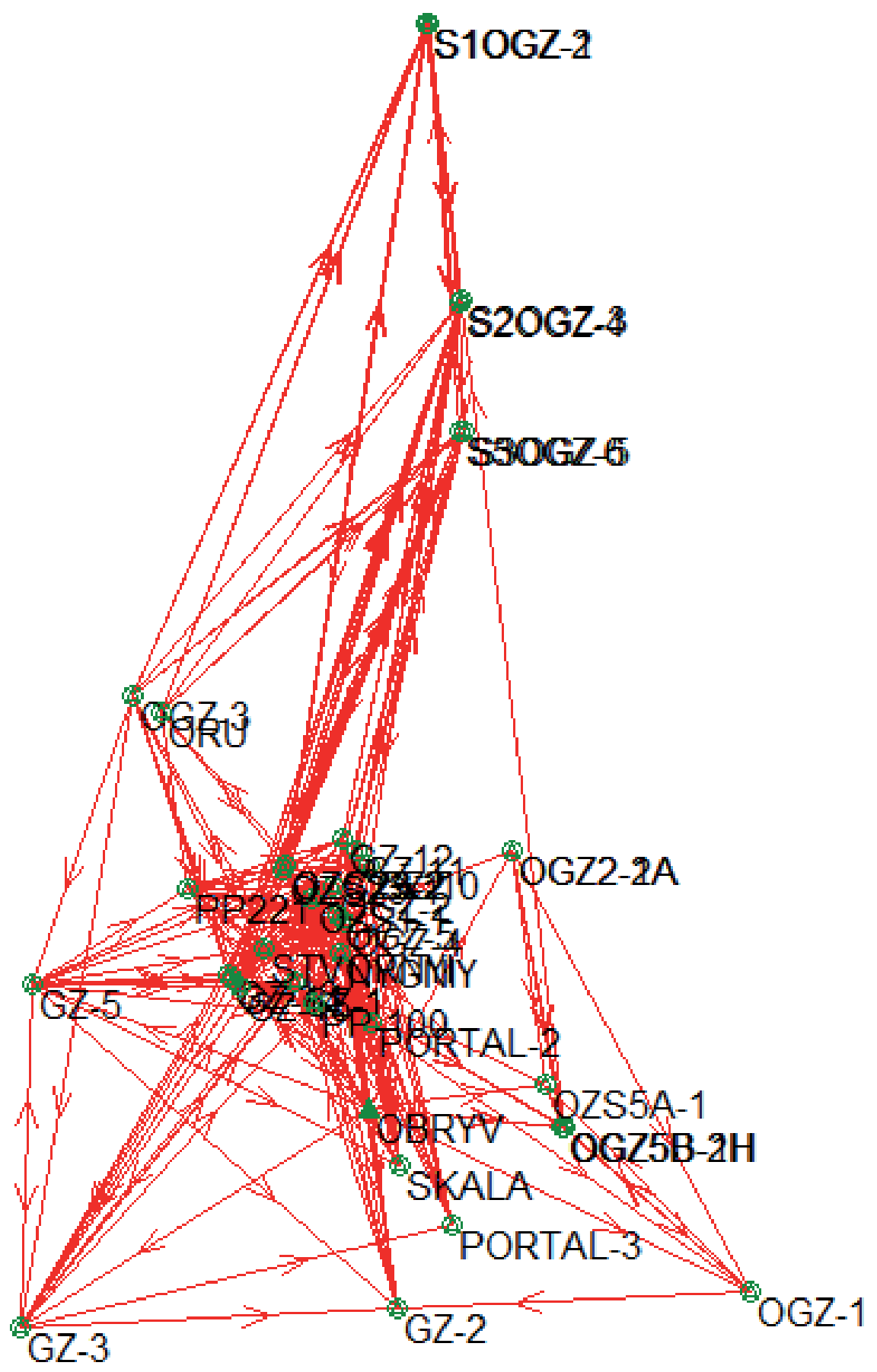

Fig. 2. The general scheme for measuring vectors of control geodetic network of Dniester HPPS (October 2012) 


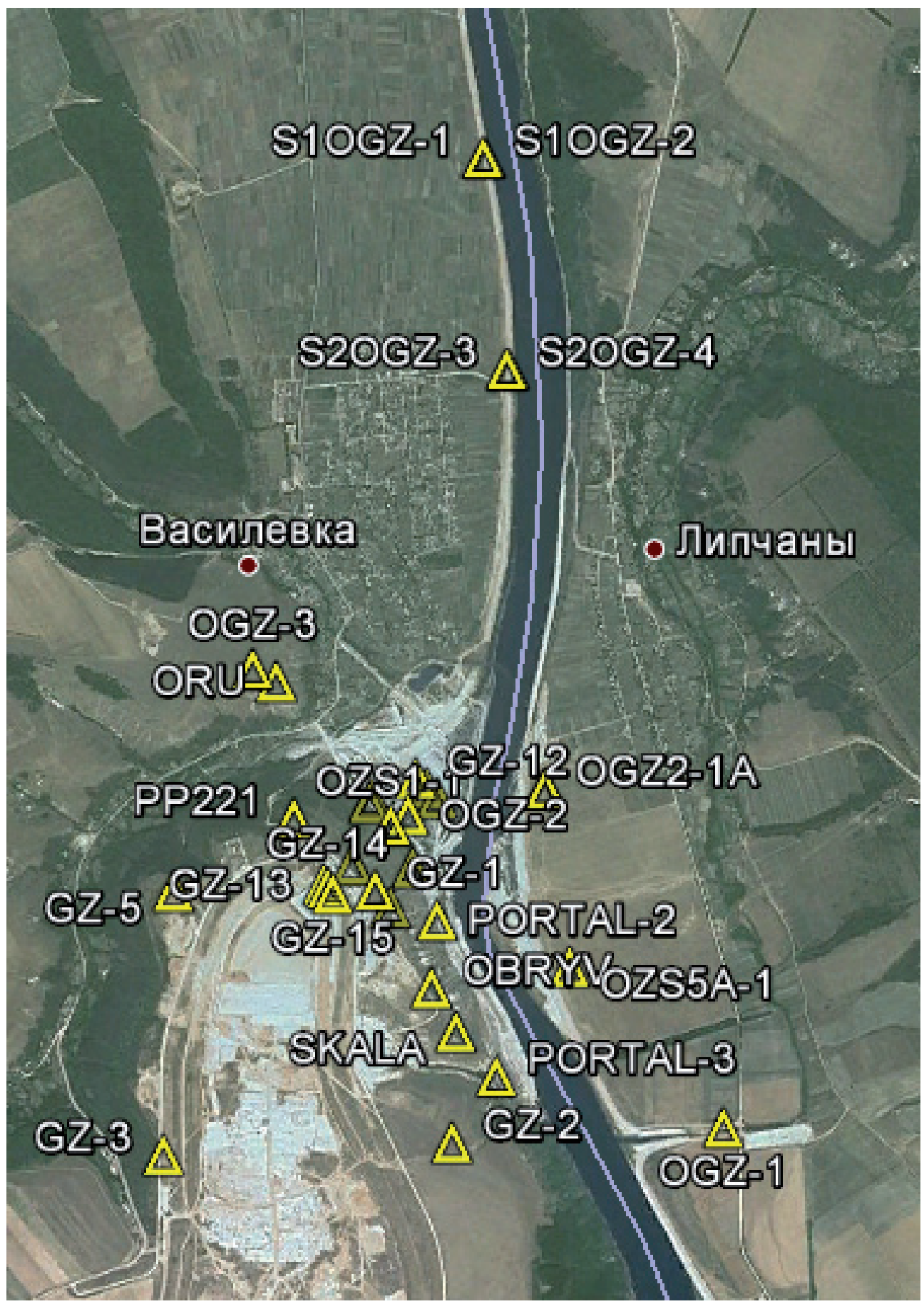

Fig. 3. The scheme of the control geodetic network points location on the satellite image 
For the implementation of the measurement, the special work program was developed. It takes into account the configuration of the control geodetic network and minimizes transportation costs when moving between points [3].

According to this program three independent sessions of GPS-observations with duration 6 hours using different satellite signals receivers were conducted for each of the points of the control geodetic network. Total observation time at each of the points is not less than 18 hours.

For the implementation of the last cycle of the GPS-measurements (October 2012) nine dual-frequency GPS-receivers were used:

- Leica GX-1230GG - 4,

- Novatel DL-V3-L1/L2G - 2,

- Trimble R7 -2,

- Javad Maxor - 1.

Observations were performed on thirty-eight points of the network. The lengths of the measured vectors are in the range from $5.0 \mathrm{~m}$ to $4.2 \mathrm{~km}$.

Processing of measured vectors was made using software "Leica Geo Office Combined" (LGO), with the calculation of the corrections for the influence of the ionosphere on observational data and taking into account the tropospheric refraction by the Hopfield model. Totally during twelve cycles 369 vectors on the points of the control geodetic network were measured. According to the results of the adjustment of the GPS-observation data the accuracy of determination of plane coordinates of the points does not exceed $\pm 2 \mathrm{~mm}$.

Points of the control geodetic network, which in the vast majority embedded in the open areas and the antennas of the GPS-receivers are receiving a qualitative satellite signal. For observations on slope stability on the part of the right bank of the Dniester River it is planned to install special ranging marks to monitor displacements of slopes below the upper reservoir. On these points the closeness of the celestial sphere on west direction is 20-30 degrees. Additionally the large number of plantings (trees and shrubs) will cause a multibeam effect (reception of re-reflected signals). These factors will have a negative effect on the accuracy of the GPS-observations.

In 2012 the reciprocal linear observations on the points of control geodetic network were held. Measurements were made with robotic total station (Total Station Positioning System TCRP-1201 of Leica company. The mean square error (RMS) in the measuring horizontal and vertical angles by one trial was 1 and measuring lines is $\pm(1 \mathrm{~mm}+1.5 \mathrm{ppm})$.

Table 1 shows the vectors and their differences collected from satellite and linear measurements.

Points OBRYV and STVORNYI are located on the right bank of the Dniester River and the measurements were carried out on the points on the left bank. The vertical difference between them is $130 \mathrm{~m}$. Points GZ13-GZ-15 are located on the building of the HPPS water intake. 
As seen from Table 1, the maximum difference in linear measurements by total station in both directions does not exceed $3.2 \mathrm{~mm}$, and on average is equal to $1.6 \mathrm{~mm}$. Differences of measured vectors obtained from satellite and ground-based observations do not exceed $2.3 \mathrm{~mm}$, what will provide the necessary accuracy in the observations of deformations slopes.

Table 1. Vectors and their differences resulting from satellite and linear measurements

\begin{tabular}{|c|c|c|c|c|c|c|c|}
\hline \multirow{3}{*}{ No. } & \multirow{3}{*}{\multicolumn{2}{|c|}{ Name of vector }} & \multicolumn{4}{|c|}{ Length of vector [m] } & \multirow{3}{*}{$\begin{array}{c}D_{\mathrm{GPS}}-D_{\mathrm{TCRP}} \\
{[\mathrm{m}]}\end{array}$} \\
\hline & & & \multicolumn{2}{|c|}{ GPS } & \multicolumn{2}{|c|}{ TCRP 1201} & \\
\hline & & & $D_{\mathrm{GPS}}$ & RMS & $D_{\text {TCRP }}$ & $D_{\text {direct }}-D_{\text {reverse }}$ & \\
\hline 1 & OBRYV & OGZ-1 & 1591.9383 & 0.0001 & 1591.9371 & 0.0018 & 0.0012 \\
\hline 2 & OBRYV & OZS5A-1 & 684.2568 & 0.0000 & 684.2559 & 0.0025 & 0.0009 \\
\hline 3 & OBRYV & OGZ2-1A & 1114.7608 & 0.0001 & 1114.7585 & 0.0032 & 0.0023 \\
\hline 4 & OBRYV & OGZ2-2A & 1110.1854 & 0.0000 & 1110.1839 & 0.0011 & 0.0015 \\
\hline 5 & OBRYV & OGZ5B-1H & 749.4259 & 0.0000 & 749.4239 & 0.0011 & 0.0020 \\
\hline 6 & OBRYV & OGZ5B-2H & 740.0407 & 0.0000 & 740.0395 & 0.0001 & 0.0012 \\
\hline 7 & STVORNYI & OGZ2-1A & 1009.3891 & 0.0001 & 1009.3868 & 0.0028 & 0.0023 \\
\hline 8 & STVORNYI & OGZ5A-1 & 1178.5900 & 0.0001 & 1178.5889 & 0.0029 & 0.0011 \\
\hline 9 & GZ-13 & GZ-14 & 26.5482 & 0.0002 & 26.5485 & 0.0003 & -0.0003 \\
\hline 10 & GZ-14 & GZ-15 & 36.4487 & 0.0002 & 36.4490 & 0.0003 & -0.0003 \\
\hline 11 & OBRYV & OGZ-1 & 62.9953 & 0.0001 & 62.9956 & 0.0011 & -0.0003 \\
\hline
\end{tabular}

During construction of the HPPS the conditions of GPS-observations were changing from cycle to cycle as openness of the celestial sphere for GNSS measurements is reducing, which leads to additional errors and loss of accuracy of the plane coordinates of the control geodetic network. To improve the accuracy of the determination of the points coordinates under unsatisfactory conditions of reception of satellite signals we used ground precision geodetic techniques. The points (GZ-10 - GZ-12) mounted on water outlet of Dniester HPPS can be considered as weak points for GPS-observations. On these points the reception of signals from satellites systems GNSS is significantly impeded. Points are located in straight close to technological and building structures. These factors affect negatively on the quality of phase GNSS measurements. Determination of coordinates on these points had been made by linear-angular observations. Control points of geodetic network STVORNYI and OGZ2-1A were taken as initial. The observation network has the form of triangles. Figure 4 shows a scheme of linear-angular measurements on the Dniester HPPS. 


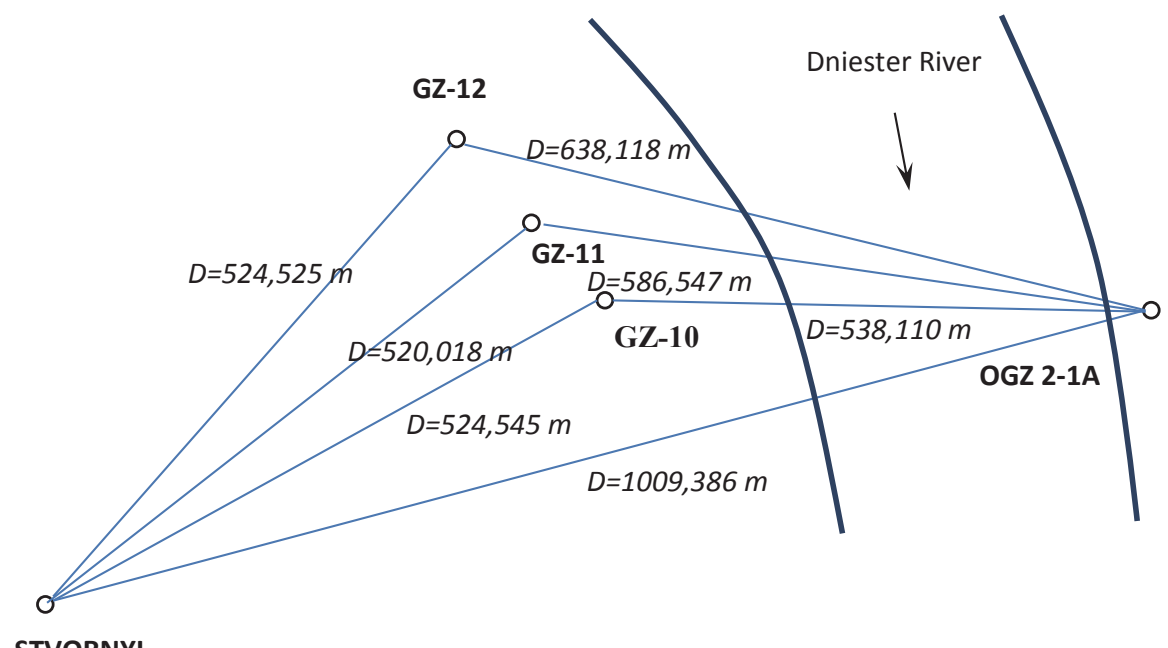

Fig. 4. Scheme of linear-angular measurements on the Dniester HPPS

Observations are made by robotic total station TCRP-1201. The angles and lines are measured in automatic mode by 8 trials. Figure 5 shows the process of linear-angular observations on the point STVORNYI. Measurements are made with the use of vehicles during four hours. Preliminary processing of non-simultaneous observations was done with the introduction of corrections for meteorological conditions (temperature and pressure).

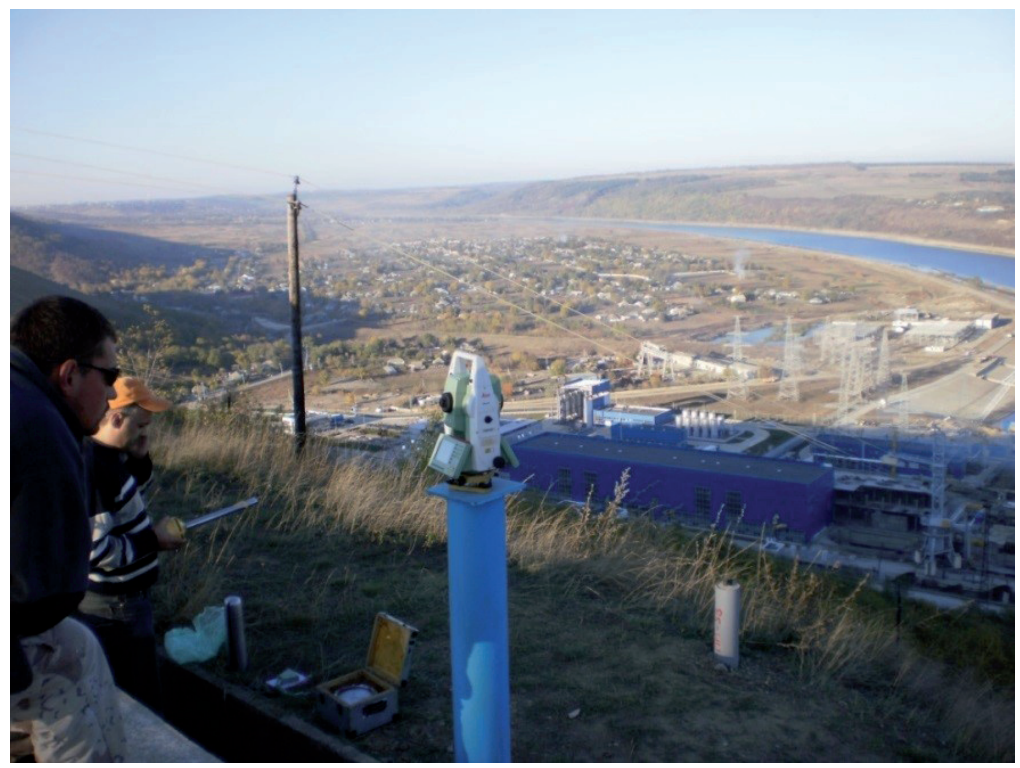

Fig. 5. Observations by TCRP-1201 at point STVORNYI 
The adjustment of plane and altitude experimental network was implemented using software complex "MG Networks" based on the results of preliminary processing and making assumptions about the same refractive field on the whole area. Evaluation of the accuracy of point position is given in Table 2.

Table 2. Results of adjustment of plane and altitude experimental network under the same influence of vertical refraction

\begin{tabular}{|c|c|c|c|}
\hline \multirow{2}{*}{ Name of point } & \multicolumn{3}{|c|}{ Mean square error of points position } \\
\cline { 2 - 4 } & $M_{\mathrm{X}}[\mathrm{m}]$ & $M_{\gamma}[\mathrm{m}]$ & $M_{H}[\mathrm{~m}]$ \\
\hline \hline OGZ 2-1A & 0.0006 & 0.0013 & 0.0011 \\
\hline GZ-10 & 0.0014 & 0.0015 & 0.0013 \\
\hline GZ-11 & 0.0014 & 0.0015 & 0.0013 \\
\hline GZ-12 & 0.0016 & 0.0016 & 0.0013 \\
\hline
\end{tabular}

Elevations of reciprocal leveling are usually determined by calculating the average value of the off height/superiority direct $h_{A B}$ and reverse $h_{B A}$ values of elevations $[4,5]$ :

$$
\begin{aligned}
& \bar{h}_{A B}=\frac{h_{A B}-h_{B A}}{2}=\frac{D_{A B} \cos Z_{A B}-D_{B A} \cos Z_{B A}}{2}+\frac{\left(i_{A}-v_{B}\right)-\left(i_{B}-v_{A}\right)}{2}+ \\
& +\frac{\left(1-k_{A B}\right) D_{A B}^{2} \sin ^{2} Z_{A B}-\left(1-k_{B A}\right) D_{B A}^{2} \sin ^{2} Z_{B A}}{4 R}+ \\
& +\frac{u_{A}^{\prime \prime} D_{A B} \sin Z_{A B}-u_{B}^{\prime \prime} D_{B A} \sin Z_{B A}}{2 \rho^{\prime \prime}}
\end{aligned}
$$

where:

$D_{A B}$ - inclined distance between points of observation, measured by electronic total station with the introduction of corrections for the meteorological conditions of the light beam,

$A_{A B^{\prime}} Z_{B A}-$ measured zenith angles, respectively for direct and reverse traverse of observations,

$i_{A^{\prime}} i_{B}$ - heights of total stations at corresponding points,

$v_{A^{\prime}} v_{B}$ - heights of bearing targets at corresponding points,

$R$ - the radius of Earth curvature $(R=6380 \mathrm{~km})$,

$k_{A B}, k_{B A}$ - the coefficients of the vertical refraction along the observation line on points $A$ and $B$,

$u_{A}^{\prime \prime}, u_{B}^{\prime \prime} D$ - deviations of plumbing lines on observation points,

$\rho^{\prime \prime}=206,265$. 
Elements from the formula are shown in Figure 6.

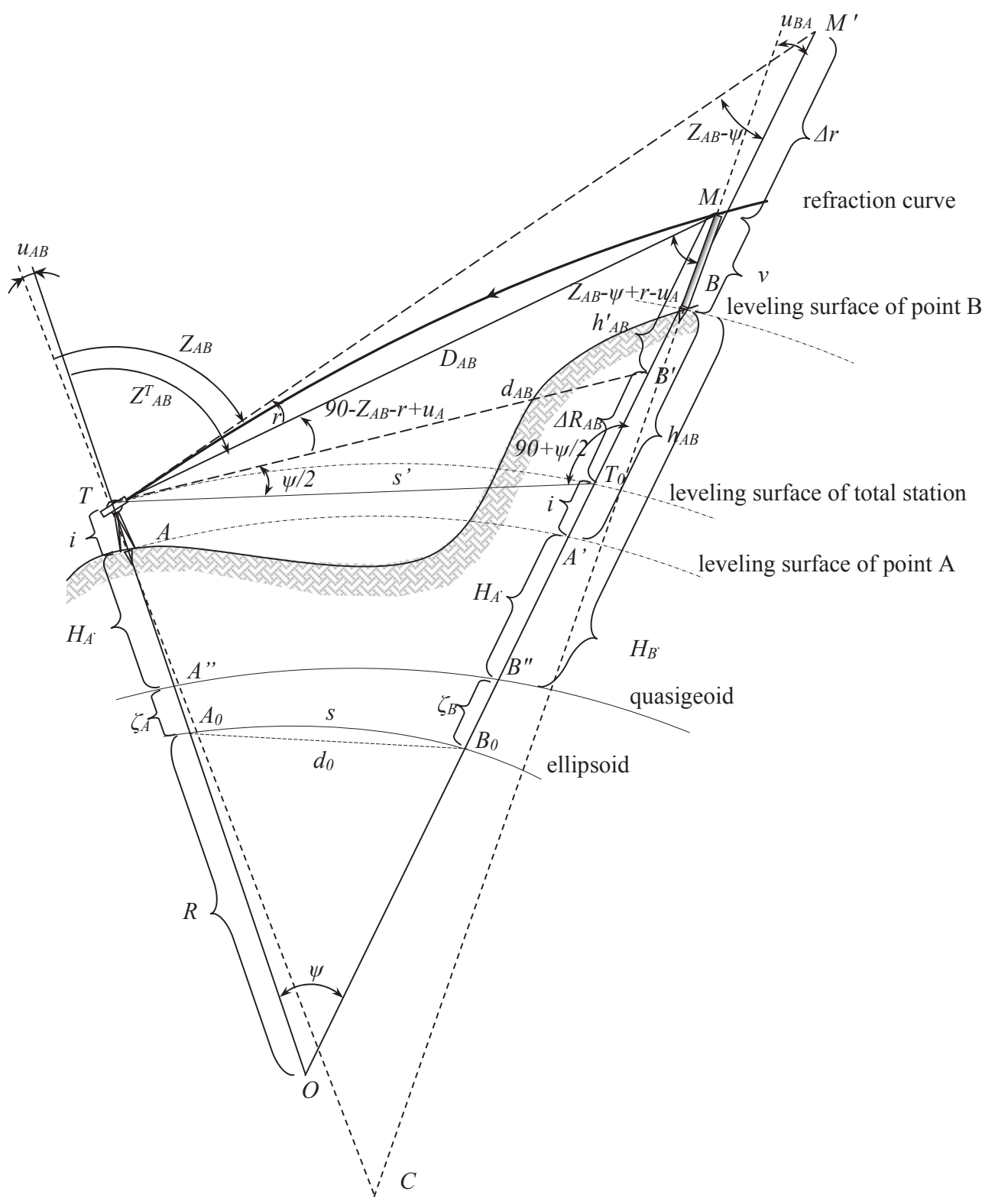

Fig. 6. Unilateral trigonometric leveling 
Preliminary calculations are performed on the condition of the uncertainty of the vertical refraction and deviations of the plumbing lines:

$$
h_{A B}^{1}=D_{A B} \cos Z_{A B}+\frac{D_{A B}^{2} \sin ^{2} Z_{A B}}{2 R}+i_{A}-v_{B}
$$

and:

$$
h_{B A}^{1}=D_{B A} \cos Z_{B A}+\frac{D_{B A}^{2} \sin ^{2} Z_{B A}}{2 R}+i_{B}-v_{A}
$$

Average value of the integral coefficient of vertical refraction [6] is calculated as a result of direct and reverse elevation from equation (1) by substitution (2) and (3) and with the condition that $u_{A}^{\prime \prime}=u_{B}^{\prime \prime}$ :

where:

$$
\bar{k}_{A B}=\frac{k_{A B}+k_{B A}}{2}=\frac{\left(h_{A B}^{1}+h_{B A}^{1}\right) R}{\bar{D}_{A B}^{2} \sin ^{2} Z_{A B}}
$$

$$
\bar{D}_{A B}=\frac{D_{A B}+D_{B A}}{2} .
$$

Let's consider equations describing the dependence of the vertical refraction from the meteorological values and will set down equation system of vertical refraction coefficients for two directions $A B$ and $B A$ [5]:

$$
\begin{aligned}
& k_{A B}=12,27 \frac{P_{A B}}{T_{A B}^{2}}+503 \frac{P_{A B}}{T_{A B}^{2}} \frac{c_{A B}}{h_{e A B}^{b}} \\
& k_{B A}=12,27 \frac{P_{B A}}{T_{B A}^{2}}+503 \frac{P_{B A}}{T_{B A}^{2}} \frac{c_{B A}}{h_{e B A}^{b}}
\end{aligned}
$$

where:

$$
\begin{aligned}
P_{A B} \text { and } P_{B A}- & \text { average integral values of atmosphere air pressure for cor- } \\
& \text { responding lines [millibar], } \\
T_{A B} \text { and } T_{B A}- & \text { average integral temperature of air for corresponding } \\
& \text { lines }[\mathrm{K}], \\
C_{A B} \text { and } c_{B A}- & \text { average integral anomalous gradients of air temperature on } \\
& \text { the height } 1 \mathrm{~m} \text { for corresponding lines, } \\
h_{e A B} \text { and } h_{e B A}- & \text { equivalent height of the light beam on the underlying } \\
& \text { surface, } \\
b- & \text { degree }(b=4 / 3 \text { - for unstable stratification, } b=1-\text { for indif- } \\
& \text { ferent, } b=2 / 3 \text { for stable stratification). }
\end{aligned}
$$


It is impossible to solve equation (5) and (6) jointly without establishing a link between them.

Let's set down equations of anomalous refractions for corresponding lines $A B$ and $B A$ :

$$
\left.\begin{array}{l}
k_{a n A B}=k_{A B}-k_{n A B} \\
k_{a n B A}=k_{B A}-k_{n B A}
\end{array}\right\}
$$

where $k_{n A B^{\prime}} k_{n B A}$ - the coefficients of the normal vertical refraction on condition of dry adiabatic temperature gradient in a dry atmosphere $\gamma_{\text {adiab }}=0.0098 \mathrm{~K} / \mathrm{m}$ and is calculated by the formula [5]:

$$
k_{n}=12.27 \frac{P}{T^{2}}
$$

The ratio of coefficients of anomalous refraction $k_{a n A B}$ and $k_{a n B A}$ for directions $A B$ and $B A$ can be presented as:

$$
q_{k A B / B A}=\frac{k_{A B}-k_{n A B}}{k_{B A}-k_{n B A}}=\frac{P_{A B}}{T_{A B}^{2}} \frac{T_{B A}^{2}}{P_{B A}} \frac{c_{A B}}{c_{B A}} \frac{h_{e B A}^{b}}{h_{e A B}^{b}}
$$

where $q_{k A B / B A}-$ coefficient of refraction ratio.

Coefficient of refraction ratio is the ratio of the anomalous parts of the vertical refraction:

$$
q_{k A B / B A}=\frac{k_{a n A B}}{k_{a n B A}}
$$

Equations (7) considering (9) will be:

$$
\left.\begin{array}{l}
k_{A B}-k_{n A B}=q_{k A B / B A} k_{a n B A} \\
k_{B A}-k_{n B A}=\frac{k_{a n A B}}{q_{k A B / B A}}
\end{array}\right\}
$$

Next is summing up two equation of the system (10) and will obtain:

$$
\Sigma k-k_{n A B}-k_{n B A}=q_{k A B / B A} k_{a n B A}+\frac{k_{a n A B}}{q_{k A B / B A}}
$$


By simple transformations let's find the partial coefficients of the vertical refraction from equation (11) considering (12):

$$
\left.\begin{array}{l}
k_{A B}=k_{n A B}+\frac{q_{k A B / B A}}{q_{k A B / B A}+1}\left(\Sigma k-k_{n A B}-k_{n B A}\right) \\
k_{B A}=k_{n B A}+\frac{1}{q_{k A B / B A}+1}\left(\Sigma k-k_{n A B}-k_{n B A}\right)
\end{array}\right\}
$$

In our previous studies [7, 8], it was proposed to determine the coefficient of refraction ratio according to the fluctuations of zenith angles:

$$
q=\frac{m Z_{A B}}{m Z_{B A}}
$$

where $m Z_{A B}$ and $m Z_{B A}$ - mean square errors of zenith angle measurements at the ends of lines, calculated from trials of vertical angles observations.

The adjustment of plane and height experimental network was implemented using software complex "MG Networks" according to the results of elevation calculations with the introduction of partial corrections for vertical refraction (13). Results of point adjustment are shown in Table 3.

Table 3. Results of adjustment of plane and height experimental network taking into account the impact of vertical refraction

\begin{tabular}{|c|c|c|c|}
\hline \multirow{2}{*}{ Name of point } & \multicolumn{3}{|c|}{ Mean square error of points position } \\
\cline { 2 - 4 } & $M_{X}[\mathrm{~m}]$ & $M_{Y}[\mathrm{~m}]$ & $M_{H}[\mathrm{~m}]$ \\
\hline \hline OGZ 2-1A & 0.0006 & 0.0013 & 0.0007 \\
\hline GZ-10 & 0.0014 & 0.0015 & 0.0009 \\
\hline GZ-11 & 0.0014 & 0.0015 & 0.0009 \\
\hline GZ-12 & 0.0015 & 0.0016 & 0.0009 \\
\hline
\end{tabular}

Table 4 shows the values of RMS corrections into the measured angles, lines, and elevations that are obtained by network adjustment. The values of the corrections, as seen in Table 3, are within the measurement accuracy.

Table 4. Values of corrections to the measured angles, lines and elevations of the experimental network

\begin{tabular}{|c|c|c|c|c||}
\hline \multirow{2}{*}{ Values } & \multicolumn{3}{|c||}{ Value of corrections } \\
\cline { 2 - 5 } & $\begin{array}{c}\text { horizontal angles } \\
{["]}\end{array}$ & $\begin{array}{c}\text { lines } \\
{[\mathrm{mm}]}\end{array}$ & relative error & $\begin{array}{c}\text { elevations } \\
{[\mathrm{mm}]}\end{array}$ \\
\hline \hline RMS & 0.57 & 1.5 & $1: 416000$ & 0.9 \\
\hline Max. value & 0.63 & 1.6 & $1: 331000$ & 0.9 \\
\hline \hline
\end{tabular}




\section{Conclusions}

1. Twelfth cycle of determination of the plane coordinates of control geodetic network of Dniester HPPS was conducted using the specially developed program of GPS-observations. The accuracy of determination of point coordinates does not exceed $\pm 2 \mathrm{~mm}$.

2. Comparison of vectors derived from satellite and ground-based observations was implemented. The maximum difference between the measured lengths of vectors is $2.3 \mathrm{~mm}$.

3. Linear-angular measurements on points of experimental plane and height network were conducted. Accuracy of obtained coordinates of the points are within $1.6 \mathrm{~mm}$.

4. Corrections for the vertical refraction introduced by the method of refraction ratios have improved the results of reciprocal trigonometric leveling.

5. Implemented researches show the possibility to create plane and height networks applying the proposed method for monitoring the dynamic motions on geodynamic polygons.

\section{References}

[1] Parubačev I.A.: Zadači issledovanij neblagopriâtnyh posledstvij vzaimovozdejstviâ èkspluatiruemyh gidrotehničeskih sooruženij s geologičeskoj sredoj i ih racional'nye rešeniâ. Gidrotehničeskoe Stroitel'stvo, no 12, 1996, pp. 1-4.

[2] Sarnavs'kij V., Ovsânnìkov M.: Tektonična struktura ì geodinamičnij režim masivì porì u zonì vzaêmodï z gìdrotehničnimi sporudam GES ì GAES (na prikladì Dnìstrovs'kogo kompleksnogo gìdrovuzla). Sučasnì Dosâgnennâ Geodezičnoï Nauki ta Virobnictva, 2005, pp. 193-206.

[3] Tretâk K., Sìdorov Ì.: Optimizaciâ pobudovi geodezičnoï merežì Dnìstrovs'koï GAES suputnikovimi radionavigacì tehnologiâmi. Sučasnì Dosâgnennâ Geodezičnoï Nauki ta Virobnictva, Vip. 10, 2005, pp. 207-219.

[4] Baran P.Ì., Solovjov F.F., Čornokon' V.Â.:Trigonometrične nìvelûvannâ v ìzženerno-geodezičnih robotach. Ukrgeodezkartografiâ, Kï̈ 1996.

[5] Izotov A.A., Pellinen L.P: Issledovanie zemnoj refrakcii i metodov geodezičeskogo nivelirovaniâ. Trudy CNIIGAiK, no 102, Izdatel'stvo Geodezičeskoj Literatury, Moskva 1955.

[6] Lìtins'kij V.O., Perì S.S.: Trigonometrične nìvelûvannâv hodah geodezičnih merež zguŝennâ. [in:] Sučasnì dosâgnennâ geodezičnoï nauki ta virobnictva v Ukraïnì: Zb. nauk. prac' ZGT UTGK, Vip. 2, Nacional'nij Unìversitet “L'vìvs'ka Polìtehnika", L'vìv 2006, pp. 125-133. 
[7] Perì S.S.: Opredelenie vertikal'noj refrakcii metodami refrakcionnyh sootnošenij. Geodeziâ, Kartografiâ i Aèrofotos"emka, Vip. 50, 1990, pp. 83-87.

[8] Perij S.S.: Ispol'zovanie skorostej izmeneniâ zenitnyh rasstoânij dlâ opredeleniâ častnyh uglov refrakcij. Geodeziâ, Kartografiâ i Aèrofotos"emka, Vip. 51, 1990, pp. 83-85. 